\title{
Views of primary health care providers of the challenges to screening for intimate partner violence, Egypt
}

Eman Ibrahim, ${ }^{1}$ Nashwa Hamed ${ }^{1}$ and Lamia Ahmed ${ }^{1}$

'Department of Public Health, Faculty of Medicine, Fayoum University, Fayoum, Egypt. (Correspondence to: Eman Ibrahim: emanhanafyzoog@yahoo. com).

\begin{abstract}
Background: Health care providers can play an important role in detection of intimate partner violence within health services but barriers exist.
\end{abstract}

Aims: This study aimed to determine the barriers that health care providers in Fayoum, Egypt, consider prevent them from screening for intimate partner violence.

Methods: This was a cross-sectional study between June 2018 and January 2019. The sample was health care providers (doctors, nurses, social workers and community workers) selected from government primary care centres in all seven districts of Fayoum. A validated Arabic version of the Domestic Violence Health Care Provider Survey was used to collect data.

Results: A total of 385 health care providers ( $92.7 \%$ women) agreed to participate ( $78.6 \%$ response rate). Just over half of the participants did not have access to social workers or community workers or strategies to help victims of intimate partner violence. None had received training on screening for domestic violence. More than half (59.7\%) thought that investigating the cause of intimate partner violence was not part of medical practice. Sex was significantly associated with perceived self-efficacy, while age and occupation were significantly associated with referral management and health providers' attitude.

Conclusion: Primary health care providers perceived many barriers to screening for intimate partner violence. Training on screening for and managing intimate partner violence should be part of the professional development for all health care providers. An effective referral system is needed that ensures comprehensive services for victims.

Keywords: intimate partner violence, screening, health personnel, primary health care, Egypt

Citation: Ibrahim E; Hamed N; Ahmed L. Views of primary health care providers of the challenges to screening for intimate partner violence, Egypt. East Mediterr Health J. 2021;27(3):233-241. https://doi.org/10.26719/emhj.20.125

Received: 19/11/19; accepted: 04/03/20

Copyright (C) World Health Organization (WHO) 2021. Open Access. Some rights reserved. This work is available under the CC BY-NC-SA 3.0 IGO license (https://creativecommons.org/licenses/by-nc-sa/3.o/igo).

\section{Introduction}

Intimate partner violence is any behaviour by an intimate partner or ex-partner that causes physical, sexual or psychological harm (1,2). Intimate partner violence is an important public health problem. The World Health Organization (WHO) estimates that $35 \%$ of women have suffered either physical and/or sexual intimate partner violence or non-partner sexual violence in their lifetime $(1,2)$.

While the rates of intimate partner violence differ in low-, middle-, and high-income regions, the health effects are similar across the world (1). In all countries, women facing intimate partner violence often present in health settings and require a wide range of medical services (3) to manage health problems, not only for the women but also for their children (1). Women who experience intimate partner violence tend to use more health care services (4) and are likely to disclose abuse for the first time to a health care provider (5). Therefore, health care providers can play an important role in detection of intimate partner violence within health services if they ask women about intimate partner violence (6).

Screening for intimate partner violence within health care services is an opportunity to provide victims with information about and referral to support services $(6,7)$ as well as to discuss with them ways to cope (6-8). Health professionals are increasingly required to undertake screening for health issues including intimate partner violence in accordance with national health policies and published guidelines $(8,9)$.

Efforts of primary health care providers to screen women experiencing intimate partner violence may be undermined by various barriers; for example, not feeling confident about screening, not knowing what questions to ask or how to respond if a woman reports being abused, and feeling there is not enough time to screen (7). Barriers can also come from women who may not trust the provider enough to disclose this sensitive information. This lack of trust may be due to health care providers' attitude to and misconceptions about intimate partner violence (7-10).

In Egypt, intimate partner violence is estimated to affect $26-30 \%$ of ever-married women (11). Violence against women is considered socially acceptable to some extent, even by women, as about a third of evermarried women aged 15-49 years agree that wife beating is justified in certain circumstances (11,12). The absence of policies and the discriminatory Egyptian personal 
status - where men (father, brother or husband) have some power over women - prevent many women from reporting or proving the harm they experience which suggests the need for health care providers to screen for the intimate partner violence (12).

Our study aimed to: (i) determine the barriers to screening for inti mate partner violence as perceived by health care providers in primary health care centres in Fayoum governorate, Egypt and (ii) assess the association between health care providers' characteristics and barriers to screening for intimate partner violence.

\section{Methods}

\section{Study design and setting}

We conducted a cross-sectional descriptive study in Fayoum Governorate, south-west of Cairo, which has an area of $1827 \mathrm{~km}^{2}$ and a population of 3362413 million (13). We conducted the survey over a period of 6 months between June 2018 and January 2019. The study population was from primary health care facilities run by the health ministry in Fayoum Governorate. Fayoum Governorate is divided into seven districts, all of which have urban and rural areas: Bander El-Fayoum, Markaz El-Fayoum, Etsa, Senwres, Yuosif Elsedeek, Ebshway and Tamya districts.

\section{Study participants and sampling}

From each district, we randomly selected four primary health care facilities (a total of 28 centres), from which we selected 70 health personnel from each district to reach a sample size of 490 . The participants included doctors, nurses, social workers and community navigators (women from the catchment areas of the primary health care facilities employed by the health ministry to reach out to women residents for health education and vaccination and to carry out ministry of health surveys) from the selected primary health care facilities. The inclusion criteria were: working full time for more than 1 month, being in direct contact with patients and agreeing to participate. Participants who did not meet these criteria were excluded.

Sample size was calculated according to district population using Epi Info, 2000, based on the following assumptions: $5 \%$ precision and $95 \%$ confidence interval; this gave a sample of 408 . We increased the sample by $20 \%$ to overcome non-response to give a total sample size of 490 people. We used a purposive sampling method whereby 70 people were selected from the selected primary health care centres in each district to reach a sample of 490 participants. The final sample was 385 because 105 people declined to participate $(78.6 \%$ response rate).

\section{Study tool and data collection}

We used a validated questionnaire for data collection which was done over a period of 5 months. We collected data through face-to-face interviews at the primary health care centres. We used an Arabic version of the Domestic Violence Health Care Provider Survey Scale to as- sess the willingness of health care providers to screen for intimate partner violence as well as their actual screening activity (14). The questionnaire consisted of two sections. The first section covered the sociodemographic characteristics of the participants, including age, sex, occupation, previous training in screening for intimate partner violence and years of experience. The second section covered five aspects; perceived self-efficacy (time constraints, strategies for enquiry, access to information and confidence for enquiring about intimate partner violence) (4 items); support/referral management (4 items); conflict with ethical issues (whether providers perceive that enquiries about intimate partner violence conflict with ethical issues/rules governing their communication with clients) (6 items); attitudes of health care provider to victims (7 items); and victim/provider safety (whether providers perceive that asking the perpetrators about intimate partner violence jeopardizes the safety of victims and care provider) (10 items). A five-point Likert scale was used for each statement which ranged from 1 (strongly disagree) to 5 (strongly agree). Some of the statements are phrased in such a way that their scores need to be reversed to match with other items in the same scale. The questionnaire was developed in English which we translated into Arabic through a process of forward and backward translation with professional translators fluent in both languages. Furthermore, we tested the Arabic version on a pilot sample of 60 health care providers $(12 \%$ of the target sample) for clarity and suitability of questions, and some modifications were made. The participants of the pilot sample were not included in the final sample.

\section{Validity and reliability of the Arabic version}

The face and content validity of the translated Arabic version of the Domestic Violence Health Care Provider Survey Scale was determined in a pilot sample of 60 participants (the sample was increased from $10 \%$ to $12 \%$, to decrease the response bias) and by five experts (statisticians). A 4-point Likert scale was used for content validity with: $1=$ not relevant, 2 = somewhat relevant, $3=$ relevant and $4=$ very relevant. We considered ratings of 1 and 2 to indicate that the content was not valid and ratings of 3 and 4 that the content was valid. We used a 3-point Likert scale to assess clarity and essentiality. The clarity scale was: $1=$ not clear, $2=$ needs revision and $3=$ clear. For essentiality, the scale was: $1=$ not essential, $2=$ somewhat essential and $3=$ essential. We calculated the content validity ratio using a Lawshe sheet with the formula $(\mathrm{Ne}-\mathrm{N} / 2) /(\mathrm{N} / 2)$, where $\mathrm{Ne}$ is the number of experts indicating an item as essential and $\mathrm{N}$ is the total number of experts. We considered a content validity ratio $\geq 0.62$ to be good. We calculated the content validity index by adding all items with a content validity index equal to 1 and dividing by the total number of items. We considered a content validity index $>0.80$ to be acceptable. For items with loadings of 0.30 and above, we carried out a reliability test. As a result we dropped four items of the total 35 .

We tested significant factors $>0.30$ for internal consistency using the Cronbach alpha. We did further 
investigations to identify whether removal of the four items would improve the alpha coefficient or not and retested for reliability. We then re-examined the questions in a new factor analysis after removal of the four items until all remaining items loaded at least 0.30. We considered intraclass correlation coefficient values $>0.75$ to be excellent. We chose a Cronbach alpha $\geq 0.70$ to be significant. We ran bivariate correlations to investigate the factor distinctiveness of the final factor solution. We considered a total correlation of an item $\geq 0.4$ to be acceptable.

The intraclass correlation coefficients for the following subscales were: 0.77 for the seven items of providers' attitudes to victims; 0.73 for the 10 items of victim/provider safety; and 0.74 for the four items of system support/referral management. The intraclass correlation of the six items of the conflict with ethical issues subscale was 0.76. However, removal of two of these items increased the Cronbach alpha to 0.78. Finally, the intraclass correlation coefficient of the four items of the perceived self-efficacy subscale was 0.77. Removal of two items from this scale decreased the intraclass correlation coefficient.

\section{Data analysis}

We used SPSS, version 21 for statistical analysis. We calculated the mean and standard deviation (SD) for quantitative variables and used the independent t-test or oneway ANOVA to test significance; we considered $P \leq 0.05$ to be statistically significant. We analysed categorical data by computing percentages. We did a logistic regression analysis to test for risk factors associated with intimate partner violence barriers, presented as odds ratios (ORs) and 95\% confidence intervals (CI).

\section{Ethical considerations}

This study was approved by the Research Ethical Committee of the Faculty of Medicine, Fayoum University (Session 65 on 13 October 2019; register number R103, retrospectively registered). We obtained ethical approval and permission from the directors of the primary health care facilities to allow and facilitate data collection in their hospitals. We obtained informed verbal consent from the participants to participate in the study. We provided the participants with detailed information on their right to confidentiality and protection of their identities, the background and objectives of the study, the interview time and the voluntary nature of participation. The Research Ethical Committee of Faculty of Medicine, Fayoum University approved the use of verbal consent.

\section{Results}

Of the 385 health care providers participating in the study, $92.7 \%$ were women and $55.6 \%$ were nurses (Table 1). The greatest proportion (33.8\%) were in the age group 36-45 years followed by $26-35$ years (29.1\%). Most of the participants (57.6\%) had been working in their jobs for 11-15 years (Table 1). None of the participants had ever received training on screening for domestic violence.
Almost half of the participants (48.0\%; 185/385) said that they did not have enough time to ask about intimate partner violence, while $62.1 \%$ were not confident about making referrals for abused patients and $65.4 \%$ believed that social workers are not able to help patients experiencing intimate partner violence - because they lack guidelines or training to do this - (Figure 1). More than half of the participants had neither access to medical social workers or community advocates $(53.5 \%$; 206/385) nor strategies to help victims of intimate partner violence change their situation (55.1\%). They were also afraid that if they screened for intimate partner violence, patients who were not victims would get angry (53.5\% of participants). Most participants (75.1\%) did not want to interfere with how a couple chooses to resolve conflicts and 59.7\% believed that investigating the cause of intimate partner violence was not part of medical practice (Figure 1).

Table 2 shows the association between participants' characteristics and aspects of intimate partner violence. Mean perceived self-efficacy score was significantly associated with three characteristics of the participants: age $(P=0.029)$, sex $(P=0.037)$ and occupation $(P=0.024)$. Mean referral management score was also significantly associated with age $(P=0.001)$, while ethical issues was associated with years working in their job $(P=0.033)$. The attitude of health care providers to intimate partner violence was significantly associated with occupation $(P=0.024)$.

In the logistic regression analysis (Table 3), female sex was significantly associated with perceived self-efficacy

\begin{tabular}{|c|c|c|}
\hline Characteristic & $\begin{array}{c}\text { No. } \\
(n=385)\end{array}$ & $\%$ \\
\hline \multicolumn{3}{|l|}{ Age(years) } \\
\hline$<25$ & 32 & 8.3 \\
\hline $26-35$ & 112 & 29.1 \\
\hline $36-45$ & 130 & 33.8 \\
\hline $46-55$ & 79 & 20.5 \\
\hline$>55$ & 32 & 8.3 \\
\hline \multicolumn{3}{|l|}{ Sex } \\
\hline Male & 28 & 7.3 \\
\hline Female & 357 & 92.7 \\
\hline \multicolumn{3}{|l|}{ Job description } \\
\hline Specialist & 22 & 5.7 \\
\hline Family physician & 31 & 8 \\
\hline Resident & 55 & 14.3 \\
\hline Nurse & 214 & 55.6 \\
\hline Social worker & 63 & 16.4 \\
\hline \multicolumn{3}{|l|}{ Years in job } \\
\hline $1-5$ & 56 & 14.5 \\
\hline $6-10$ & 28 & 7.3 \\
\hline $11-15$ & 79 & 20.5 \\
\hline$>15$ & 222 & 57.6 \\
\hline
\end{tabular}




\section{Figure 1 Distribution of participants according to attitude and barriers to screening for intimate partner violence}

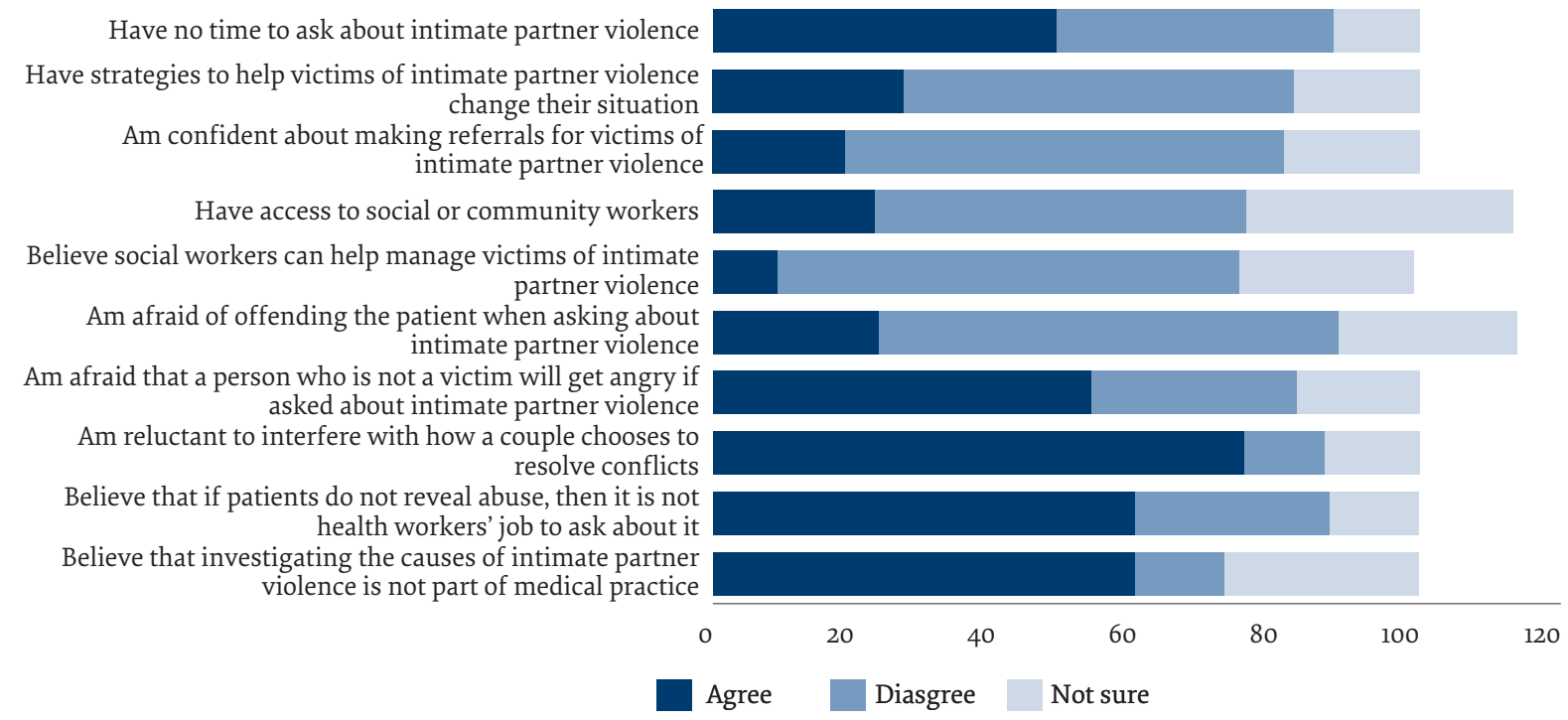

$(\mathrm{OR}=1.612 ; 95 \% \mathrm{CI}: 1.072-2.424)$. In addition, being a social worker was significantly associated with health provider attitude $(\mathrm{OR}=0.849 ; 95 \% \mathrm{CI}: 0.758-0.950)$.

\section{Discussion}

According to WHO, a high prevalence of mental problems, negative health outcomes and suicidal attempts have been detected among those who have experienced intimate partner violence, which make it a serious public health problem that needs to be addressed (15). Reducing or eliminating intimate partner violence requires a deep understanding of cultural norms as well as the challenges that many health care providers face when dealing with this issue among their patients. Hence, our study

\begin{tabular}{|c|c|c|c|c|c|c|c|c|c|c|}
\hline \multirow[t]{2}{*}{ Characteristic } & \multicolumn{2}{|c|}{ Self-efficacy } & \multicolumn{2}{|c|}{$\begin{array}{c}\text { Referral } \\
\text { management }\end{array}$} & \multicolumn{2}{|c|}{ Ethical issues } & \multicolumn{2}{|c|}{ Provider attitude } & \multicolumn{2}{|c|}{$\begin{array}{c}\text { Victim/provider } \\
\text { safety }\end{array}$} \\
\hline & Mean (SD) & P-value & Mean (SD) & P-value & Mean (SD) & P-value & Mean (SD) & $P$-value & Mean (SD) & P-value \\
\hline \multicolumn{11}{|l|}{ Age (years) } \\
\hline$<25$ & $2.00(1.08)$ & 0.029 & $5.38(1.95)$ & 0.001 & $4.13(1.88)$ & 0.152 & $9.03(2.31)$ & 0.507 & $3.31(1.62)$ & 0.301 \\
\hline $26-35$ & $2.38(0.89)$ & & $5.73(2.28)$ & & $4.30(1.38)$ & & $9.19(2.38)$ & & $3.94(1.35)$ & \\
\hline $36-45$ & $2.55(0.92)$ & & $5.36(2.39)$ & & 4.64 (1.29) & & $9.13(2.62)$ & & $3.92(1.52)$ & \\
\hline $46-55$ & $2.62(1.16)$ & & $6.90(3.24)$ & & $4.32(1.71)$ & & $9.54(3.27)$ & & $3.96(1.74)$ & \\
\hline$>55$ & $2.34(1.21)$ & & $6.31(3.04)$ & & $4.75(1.41)$ & & $9.91(2.69)$ & & $3.81(1.55)$ & \\
\hline \multicolumn{11}{|l|}{ Sex } \\
\hline Male & $2.07(1.18)$ & 0.037 & $6.07(2.49)$ & 0.667 & $4.43(1.20)$ & 0.962 & $9.21(2.25)$ & 0.880 & $3.46(1.10)$ & 0.144 \\
\hline Female & $2.48(0.99)$ & & $5.85(2.65)$ & & $4.44(1.50)$ & & $9.29(2.71)$ & & $3.90(1.56)$ & \\
\hline \multicolumn{11}{|l|}{ Occupation } \\
\hline Specialist & $2.41(1.18)$ & 0.024 & $7.14(2.71)$ & 0.177 & $4.32(1.67)$ & 0.107 & $9.00(2.78)$ & 0.024 & 3.91 (1.19) & 0.345 \\
\hline $\begin{array}{l}\text { Family } \\
\text { physician }\end{array}$ & $2.46(1.25)$ & & $6.04(3.38)$ & & $4.00(0.83)$ & & $8.58(2.47)$ & & $3.38(1.66)$ & \\
\hline Resident & $2.38(0.76)$ & & $5.71(1.99)$ & & $4.45(1.41)$ & & $9.29(2.65)$ & & $3.98(1.46)$ & \\
\hline Nurse & $2.50(1.02)$ & & $5.89(2.64)$ & & $4.42(1.55)$ & & $9.07(2.72)$ & & $3.88(1.59)$ & \\
\hline Social worker & $2.52(0.93)$ & & $5.38(2.81)$ & & $4.83(1.39)$ & & $10.32(2.51)$ & & $4.02(1.52)$ & \\
\hline \multicolumn{11}{|l|}{ Years in job } \\
\hline $1-5$ & $2.30(0.87)$ & 0.201 & $5.62(2.13)$ & 0.160 & $4.64(1.27)$ & 0.033 & $9.34(2.47)$ & 0.867 & $4.20(1.48)$ & 0.078 \\
\hline $6-10$ & $2.18(0.77)$ & & $5.36(2.97)$ & & $3.61(1.66)$ & & $8.86(2.74)$ & & $3.18(1.22)$ & \\
\hline $11-15$ & $2.39(1.09)$ & & $5.47(2.37)$ & & $4.47(1.59)$ & & $9.32(2.71)$ & & $3.82(1.69)$ & \\
\hline$>15$ & $2.55(1.04)$ & & $6.11(2.78)$ & & $4.48(1.44)$ & & $9.33(2.73)$ & & $3.90(1.51)$ & \\
\hline
\end{tabular}

$S D=$ standard deviation. 


\begin{tabular}{|c|c|c|c|}
\hline Factors associated with: & B & P-value & OR $(95 \% \mathrm{CI})$ \\
\hline \multicolumn{4}{|l|}{ Self-efficacy } \\
\hline Age (> 35 years) & 0.093 & 0.451 & $1.10(0.86-1.40)$ \\
\hline Sex (female) & 0.477 & 0.022 & $1.61(1.07-2.42)$ \\
\hline Occupation (social worker) & -0.136 & 0.417 & $0.87(0.63-1.21)$ \\
\hline Years in job $(>15)$ & -0.152 & 0.186 & $0.86(0.69-1.08)$ \\
\hline \multicolumn{4}{|l|}{ Referral management } \\
\hline Age (>35 years)) & 0.021 & 0.660 & $1.02(0.93-1.12)$ \\
\hline Sex (female) & -0.134 & 0.122 & $0.87(0.74-1.04)$ \\
\hline Job (social worker) & 0.104 & 0.074 & $1.11(0.99-1.25)$ \\
\hline Years in job $(>15)$ & -0.070 & 0.111 & $0.93(0.86-1.02)$ \\
\hline \multicolumn{4}{|l|}{ Ethical issues } \\
\hline Age (> 35 years) & 0.142 & 0.121 & $1.15(0.96-1.38)$ \\
\hline Sex (female) & -0.161 & 0.328 & $0.85(0.62-1.18)$ \\
\hline Occupation (social worker) & -0.181 & 0.161 & $0.83(0.65-1.03)$ \\
\hline Years in job $(>15)$ & -0.044 & 0.600 & $0.96(0.81-1.13)$ \\
\hline \multicolumn{4}{|l|}{ Provider's attitude } \\
\hline Age (> 35 years) & 0.007 & 0.872 & $1.01(0.92-1.10)$ \\
\hline Sex (female) & 0.005 & 0.945 & $1.01(0.86-1.17)$ \\
\hline Occupation (social worker) & -0.164 & 0.004 & $0.85(0.76-0.95)$ \\
\hline Years in job $(>15)$ & -0.007 & 0.868 & $0.99(0.92-1.08)$ \\
\hline \multicolumn{4}{|l|}{ Victim/provider safety } \\
\hline Age (> 35 years) & -0.133 & 0.135 & $0.88(0.74-1.04)$ \\
\hline Sex (female) & 0.238 & 0.129 & $1.27(0.93-1.73)$ \\
\hline Occupation (social worker) & 0.054 & 0.611 & $1.06(0.86-1.30)$ \\
\hline Years in job $(>15)$ & 0.042 & 0.597 & $1.04(0.89-1.22)$ \\
\hline
\end{tabular}

$\mathrm{OR}=$ odds ratio; $\mathrm{CI}=$ confidence interval.

attempted to explore these barriers and suggest some effective solutions.

Similar to other studies $(16,17)$, we categorized barriers faced by health care providers in dealing with intimate partner violence into five groups: perceived self-efficacy, perceived system support and referral management, ethical issues, providers' attitudes, and perceived victimrelated issues. Our results suggest that ethical issues, perceived victim-related issues and perceived system support and referral management are the most important barriers that could hinder screening for intimate partner violence. Most of our participants chose not to interfere with how couples manage conflicts and thought that nonabused patients might get angry if they are asked about intimate partner violence. This results concurs with a study done in a very similar context in Mounofia, Egypt (18) but conflicts with a Canadian study that found that most participants believed identifying intimate partner violence was very relevant to clinical practice (19). Two main characteristics of Egyptian society, religiosity and conservatism, could be the reasons behind our finding. On the other hand, the fact that none of our participants had had training on screening for intimate partner violence in the past 5 years means they were not well equipped to deal with this issue. Other studies have found that implementing intimate partner violence screening programmes improves the knowledge, attitudes and selfefficacy of health care providers about intimate partner violence and screening (20-22).

Health care providers' cultural competency could be beneficial in detecting the signs of exposure to intimate partner violence and dealing with victims in a culturally sensitive way. However, insufficient training on, inadequate experience of and absence of support resources for intimate partner violence mean health care providers rely on their cultural beliefs that tend to see domestic violence as an unimportant personal issue. These beliefs could negatively affect their attitude to screening cases of intimate partner violence and their preparedness to do so. This was clearly demonstrated as about three quarters of our participants chose not to interfere with how a couple manages conflict, and two thirds believed that intervening in intimate partner violence was not part of their medical practice.

Our participants' attitudes to victims of intimate partner violence as a barrier to screening for intimate partner violence was significantly associated with their occupation. Social workers and nurses had a more positive attitude to victims, while family physicians had the least favourable attitude. This finding concurs with the findings of another Egyptian study that reported that physicians thought that screening for intimate 
partner violence was not important because of its social acceptability in the Middle East (23). A Brazilian study also found that physicians had little sympathy for victimized women (24). Many cultural, gender and religious norms could explain these findings. Within the Arabic culture, women are expected to follow the culture on marital relationships and not disclose intimate partner violence to others, including to health care providers as found in a Saudi study only $6.5 \%$ of women who had intimate partner violence related injuries had reported these injuries to a health-care provider (25). Women who choose to report it face several obstacles, including stigma, a lack of interest by the police or the legal system, as well as inadequate criminal laws that explicitly criminalize domestic violence and marital rape. This leads many women who are subjected to domestic violence to suffer in silence.

The other main barriers to screening as reported by more than half of our participants were time constraints and a lack of strategies to handle intimate partner violence. This is consistent with the findings of other studies $(18-23,26)$. On the other hand, an American study found those two barriers were reported by only $9.4 \%$ of their participants (27).

The two perceived self-efficacy barriers were significantly associated with age, sex and job of the health care provider. Female providers showed more perceived self-efficacy than males which is in line with a Swedish study that also found that health care providers who perceived a high self-efficacy in screening were more likely to screen for intimate partner violence (28). This association may be due to high representation of women in our study sample and women may show more readiness to screen for intimate partner violence out of sympathy for fellow women. Social workers perceived a higher self-efficacy than other providers which is consistent with studies conducted in Nigeria and Uganda that found Ugandan doctors had lower self-efficacy than other professions and social workers had higher self-efficacy $(29,30)$. This differs from a Lebanese study that found that physicians considered themselves well positioned to manage intimate partner violence (31).

Confidence about referring a victim of intimate partner violence is an important component of the perceived support system, which in turn, is associated with an increased likelihood to screen for intimate partner violence (28-32). In our study, most participants were not confident about making referrals for abused women, which affected their proactivity to try and detect victims of intimate partner violence. A Nigerian study found that health care providers who had a high efficacy in handling intimate partner violence, few fears of offending clients, professional preparedness, and available support networks were more likely to screen for intimate partner violence (29).

Age significantly affected both perceived self-efficacy and system support and referral in our study. This finding agrees with, and may even be explained by a study that found that older primary health care workers were more likely to screen for intimate partner violence (32).
Our study showed that sex was a significant predictor of health care providers' self-efficacy. However, this result may be biased by large numbers of female participants in our study (92.7\%) compared with males $(3.7 \%)$. which could affect the reliability of this finding.

More than half of our participants did not have any access to social workers or community advocates and two thirds claimed social workers were unable to provide help. This finding differs from another Egyptian study where one fifth of participants claimed the unavailability of the necessary referrals to help victims (23).

This is consistent with findings of a study done among Jordanian nurses (26). This unavailability of support resources is problematic and could be correlated with a reluctance of health care providers to intervene or even report cases of intimate partner violence.

As far as we know this is the first study dealing with intimate partner violence in our governorate. We covered all seven districts of Fayoum governorate, even remote areas, and had a response rate of $78.5 \%$. Our study had some limitations. It was carried out in settings run by the health ministry, which serve low-income populations where physicians, nurses and social workers do not receive the training they need to effectively screen for intimate partner violence. Therefore, it may not be possible to generalize our results to other governorates in Egypt or other health care facilities, such as teaching or private facilities which have different organizational structures. Furthermore, the responses were the participants' perceptions about dealing with intimate partner violence (no time, no strategies to help) rather than the actual status if they had to deal a real situation, and the two may differ Selection bias is another limitation, as the views of those who did not participate in the study may be different from those who were included. In spite of omitting some questions from the original questionnaire (related to provider and victim safety) that we considered might contradict our culture (mainly on sexual violence), some health care providers were reluctant to complete the questionnaire, especially in rural areas. In addition, we could not properly assess barriers to intimate partner violence screening according to sex because of the under-representation of male participants compared to females. Focus group discussion could be a better choice to maximize accuracy and the amount of information collected, but we could not undertake such discussions because the health care providers had limited time.

In view of our findings, training on screening for and managing intimate partner violence should be part of the professional development for all health care providers. Partnership between the health and social affairs ministries, as well as nongovernmental organizations, is recommended to provide cross-training and develop an effective referral system that ensures comprehensive services for victims. 


\section{Acknowledgement}

We thank the directors of the primary healthcare centres who allowed us to carry out the survey, and the data collectors and participants for their time in completing the questionnaire.

Funding: None.

Competing interests: None declared.

\section{Points de vue des prestataires de soins de santé primaires sur les difficultés du dépistage de la violence entre partenaires intimes (Égypte) \\ Résumé}

Contexte : Les prestataires de soins de santé peuvent jouer un rôle important dans la détection de la violence entre partenaires intimes au sein des services de santé, mais des obstacles existent à cet égard.

Objectifs : La présente étude visait à déterminer les obstacles que les prestataires de soins de santé à Fayoum (Égypte) considèrent comme des entraves au dépistage de la violence entre partenaires intimes.

Méthodes : Il s'agissait d'une étude transversale réalisée entre juin 2018 et janvier 2019. L'échantillon était composé de prestataires de soins de santé (médecins, infirmiers, travailleurs sociaux et agents communautaires) sélectionnés dans les centres de soins primaires gouvernementaux des sept districts de Fayoum. Une version arabe validée de l'enquête auprès des prestataires de soins de santé sur la violence domestique a été utilisée pour collecter les données.

Résultats : Au total, 385 prestataires de soins de santé (92,7\% de femmes) ont accepté de participer (taux de réponse de 78,6\%). Un peu plus de la moitié des participants n'avaient pas accès à des travailleurs sociaux ou à des agents communautaires. De même, ils ne pouvaient pas recourir à des stratégies pour aider les victimes de la violence exercée par un partenaire intime. Aucun n'avait reçu de formation au dépistage de la violence domestique. Plus de la moitié $(59,7 \%)$ pensaient que l'enquête sur la cause de la violence exercée par le partenaire intime ne faisait pas partie de la pratique médicale. Il y avait une corrélation importante entre le sexe et l'auto-efficacité perçue, tandis que l'âge et la profession étaient significativement associés à la gestion de l'orientation-recours et à l'attitude des prestataires de santé.

Conclusion: Les prestataires de soins de santé primaires percevaient de nombreux obstacles au dépistage de la violence exercée par un partenaire intime. La formation au dépistage et à la prise en charge de la violence entre partenaires intimes devrait faire partie du développement professionnel de tous les prestataires de soins de santé. Un système efficace d'orientation-recours est nécessaire pour offrir des services complets aux victimes.

$$
\text { آراء إياء مقدمي إلرعيم، نشوى حامد، لمياء أمدية الأولية بشأن التحديات الماثلة أمام الكشف عن حالات عنف الشريك، مصر }
$$
الخلفية: يمكن أن يضطات تحول دون ذلك. مقدمو الرعاية الصحية بدور مهم في الكشف عن حالات عنف الشريك داخل الخدمات الصحية، إلا أن هناك عدة

الأهداف: هدفت هذه الدراسة إلى تحديد العقبات التي يرى مقدمو الرعاية الصحية في الفيوم، مصر أنها تعوقهم عن الكشف عن حالات عنف الشريك.

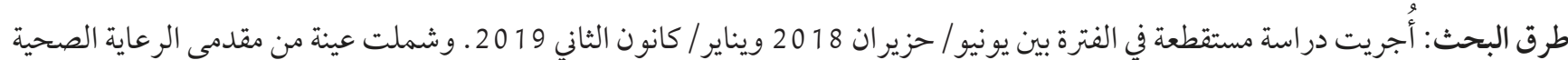

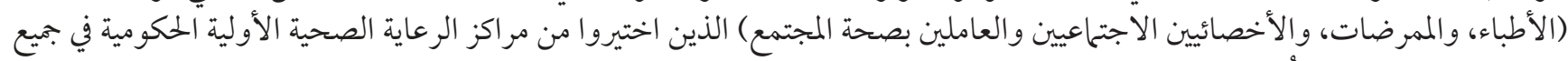

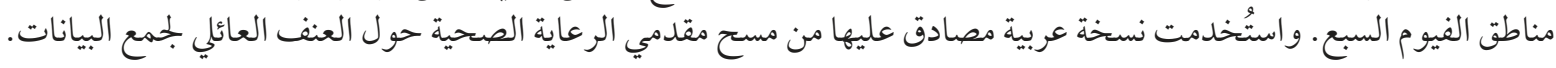

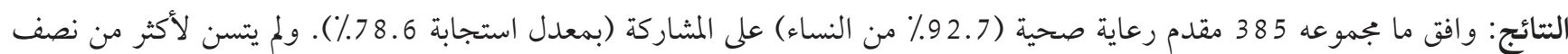

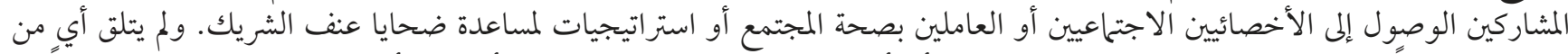

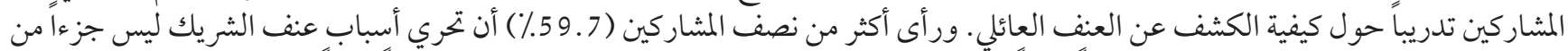

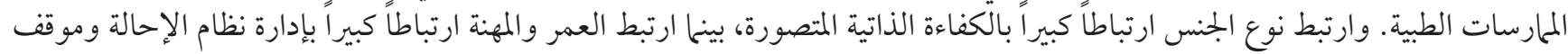
مقدمي الخلدمات الصحية.

الاستناجات: تصور مقدمو الرعاية الصحية أن هناك العديدٍ من العقبات التي تحول دون الكشف عن حالات عنف الشريك. وينبغي أن يكون

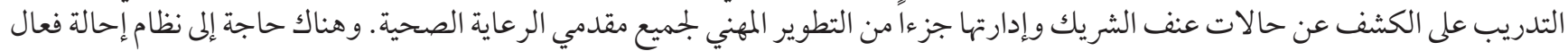
لضمان توفير خدمات شاملة للضحايا. 


\section{References}

1. Violence against women. Geneva: World Health Organization; 2016 (https://www.who.int/news-room/fact-sheets/detail/violence-against-women, accessed 22 February 2018).

2. Dillon G, Hussain R, Loxton D, Rahman S. Mental and physical health and intimate partner violence against women: a review of the literature. Int J Family Med. 2013;2013:313909. http://doi.org/10.1155/2013/313909

3. O'Doherty LJ, Taft A, Hegarty K, Ramsay J, Davidson LL, Feder G. Screening women for intimate partner violence in healthcare settings: abridged Cochrane systematic review and meta-analysis. BMJ. 2014;348:g2913. http://doi.org/10.1136/bmj.g2913

4. Kruse M, Sørensen J, Brønnum-Hansen H, Helweg-Larsen K. The health care costs of violence against women. J Interpers Violence. 2011;26(17):3494-508. http://doi.org/10.1177/0886260511403754

5. Ansara DL, Hindin MJ. Formal and informal help-seeking associated with women's and men's experiences of intimate partner violence in Canada. Soc Sci Med. 2010;70(7):1011-8. https://doi.org/10.1016/j.socscimed.2009.12.009

6. Phelan MB. Screening for intimate partner violence in medical settings. Trauma, Violence Abuse. 2007;8(2):199-213. https://doi. org/10.1177/1524838007301221

7. O'Campo P, Kirst M, Tsamis C, Chambers C, Ahmad F. Implementing successful intimate partner violence screening programs in health care settings: Evidence generated from a realist-informed systematic review. Soc Sci Med. 2011;72(6):855-66. https:// doi.org/10.1016/j.socscimed.2010.12.019

8. Miller E, McCaw B, Humphreys BL, Mitchell C. Integrating intimate partner violence assessment and intervention into healthcare in the United States: a systems approach. J Womens Health. 2015;24(1):92-9. https://doi.org/10.1089/jwh.2014.4870

9. Moyer VA. Screening for intimate partner violence and abuse of elderly and vulnerable adults: US Preventive Services Task Force Recommendation Statement. Ann Int Med. 2013;158(6):478-86. https://doi.org/10.7326/0003-4819-158-6-201303190-00588

10. Dichter ME, Wagner C, Goldberg EB, Iverson KM. Intimate partner violence detection and care in the Veterans health administration: patient and provider perspectives. Womens Health Issues. 2015;25(5):555-6o. https://doi.org/10.1016/j.whi.2015.06.006

11. Egypt Demographic and Health Survey 2014. Cairo, Egypt and Rockville, Maryland, USA: Ministry of Health and Population and ICF International; 2015 (https://dhsprogram.com/pubs/pdf/fr302/fr302.pdf, accessed 22 February 2018).

12. National Strategy for Combating Violence against Women 2015-2020. Cairo: Government of Egypt; 2015 (http://evaw-global-database.unwomen.org/fr/countries/africa/egypt/2015/national-strategy-for-combating-violence-against-women-2015-2020, accessed 22 February 2018).

13. Egypt Statistics. Population of Egypt. Cairo: Central Agency for Public Mobilization and Statistics; 2016 (http://www.capmas.gov. eg/Pages/populationClock.aspX\#, accessed 11 August 2018).

14. Maiuro RD, Vitaliano PP, Sugg NK, Thompson DC, Rivara FP, Thompson RS. Development of a health care provider survey for domestic violence psychometric properties. Am J Prev Med. 2000;19(4):245-52. https://doi.org/10.1016/s0749-3797(00)00230-0

15. Global status report on violence prevention. Geneva: World Health Organization; 2014 (https://www.who.int/violence_injury_prevention/violence/status_report/2014/en/, accessed 22 August 2018).

16. Swailes AL, Lehman EB, McCall-Hosenfeld JS. Intimate partner violence discussions in the healthcare setting: a cross-sectional study. Prev Med Rep. 2017;8:215-20. https://doi.org/10.1016/j.pmedr.2017.10.017

17. Hamberger LK, Rhodes K, Brown J. Screening and intervention for intimate partner violence in healthcare settings: creating sustainable system-level programs. J Womens Health. 2015;24(1):86-91. https://doi.org/10.1089/jwh.2014.4861

18. Arrab MM, Ibrahim SH. Effect of educational training intervention on overcoming nurses' barriers to screening intimate partner violence against women in outpatient clinics. Am J Nurs Res. 2018;6(4):198-207. https://doi.org/10.12691/ajnr-6-4-8

19. Sprague S, Kaloty R, Madden K, Dosanjh S, Mathews DJ, Bhandari M. Perceptions of intimate partner violence: a cross sectional survey of surgical residents and medical students. Int J Violence Res. 2013;5(1):2-10. https://doi.org/10.5249/jivr.v5i1.147

20. Alotaby IY, Alkandari BA, Alshamali KA, Kamel MI, El-Shazly MK. Barriers for domestic violence screening in primary health care centers. Alexandria J Med. 2013;49(2):175-80. https://doi.org/10.1016/j.ajme.2012.07.005

21. Chapin JR, Coleman G, Varner E. Yes we can! Improving medical screening for intimate partner violence through self-efficacy. J Inj Violence Res. 2011;3(1):19-23. https://doi.org/10.5249/jivr.v3i1.62

22. McCarthy J, Bianchi A. Implementation of an intimate partner violence screening program in a university health care clinic. J Am Coll Health. 2019;68(4):444-52. https://doi.org/10.1080/07448481.2019.1577864

23. Aziz MM, El-Gazzar AF. Health care providers' perceptions and practices of screening for domestic violence in Upper Egypt. Sex Reprod Healthc. 2019;20:93-9. https://doi.org/10.1016/j.srhc.2019.04.003

24. Vieira EM, dos Santos MA, Ford NJ. Seizing an opportunity to help-knowledge and attitudes of doctors and nurses toward women victimized by intimate partner violence in Brazil. Health Care Women Int. 2012;33(3):228-49. https://doi.org/10.108o/073 99332.2011.646365

25. Eldoseri HM, Tufts KA, Zhang Q, Fish JN. Adverse health effects of spousal violence among women attending Saudi Arabian primary health-care clinics. East Med Health J. 2014;20(11):717-26.

26. Al-Natour A, Gillespie GL, Felblinger D, Wang LL. Jordanian nurses' barriers to screening for intimate partner violence. Violence Against Women. 2014;20(12):1473-88. https://doi.org/10.1177/1077801214559057 
27. Faboord F, Adelman T, Mckinnon T. Barriers to screening for domestic violence among public health nurses : a descriptive study. Int J Nurs. 2014;3(1):43-50. https://doi.org/10.1002/nop2.133

28. Lawoko S, Sanz S, Helström L, Castren M. Screening for intimate partner violence against women in healthcare Sweden: prevalence and determinants. ISRN Nurs. 2011;2011:510692. https://doi.org/10.5402/2011/510692

29. John IA, Lawoko S, Svanström L. Screening for intimate partner violence in healthcare in Kano, Nigeria: extent and determinants. J Family Violence. 2011;26(2):109-16. https://doi.org/10.1007/s10896-010-9348-y

30. Lawoko S, Ochola E, Oloya G, Piloya J, Lubega M, Lawoko-Olwe W, et al. Readiness to screen for domestic violence against women in healthcare Uganda: associations with demographic, professional and work environmental factors. Open J Prev Med. 2014;4(4):145-55. https://doi.org/10.4236/ojpm.2014.44020

31. Usta J, Feder G, Antoun J. Attitudes towards domestic violence in Lebanon: a qualitative study of primary care practitioners. Br J Gen Pract. 2014;64(623):e313-20. https://doi.org/10.3399/bjgp14X680077

32. Laisser RM, Nyström L, Lugina HI, Emmelin M. Community perceptions of intimate partner violence - a qualitative study from urban Tanzania. BMC Womens Health. 2011;11:13. https://doi.org/10.1186/1472-6874-11-13 